\title{
Assessing psychological well-being measures among South African adults in the birth to twenty plus cohort
}

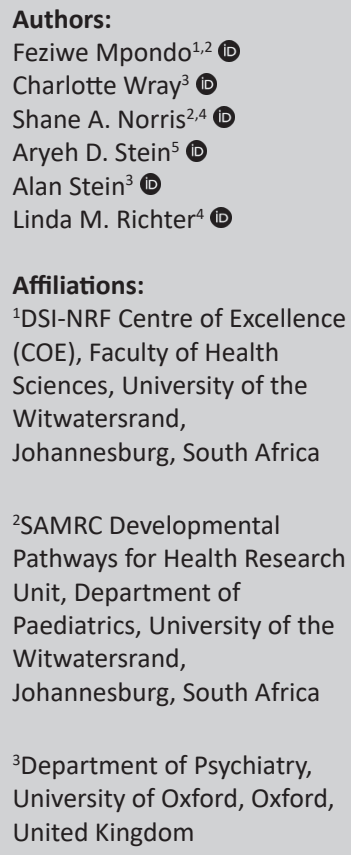

${ }^{4}$ DSI-NRF Centre of Excellence in Human Development, Faculty of Health Sciences, University of the Witwatersrand, Johannesburg, South Africa

${ }^{5}$ Hubert Department of Global Health, Rollins School of Public Health, Emory University, Atlanta, GA, United States of America

\section{Corresponding author:} Feziwe Mpondo, feziwester@gmail.com

\section{Dates:}

Received: 30 Nov. 2020 Accepted: 23 June 2021 Published: 16 Aug. 2021

\section{Read online:}

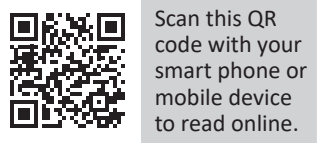

Mental health and substance use disorders account for a significant proportion of disability worldwide. In many developing countries like South Africa, mental healthcare services are often inadequate, forcing people to find their own way of coping with distress and give meaning to their experiences. Therefore, this situation necessitates the conceptualisation and characterisation of the quality-of-life indicators, as well as psychosocial strategies to promote mental well-being. The objectives of this study were to assess the psychometric properties of psychological well-being (PWB) measures in the context of urban Soweto. Data were collected from participants in the Birth to Twenty Plus cohort $(n=1327)$, in 2018-2019. Exploratory and Confirmatory Factor Analyses conducted for measures of hope, faith, social support, general self-efficacy, and life satisfaction were taken from the National Institutes of Health (NIH) Toolbox Emotion Battery. Cronbach's alpha was used to determine internal consistencies; discriminant validity was assessed using Pearson correlations. Test-retest reliability analysis was conducted on a subset of participants at three time points which were at least 2 months apart. Overall, the measures of PWB were characterised as having unidimensional factor structures, good model fit indices, high internal consistency and reliability to the paragraph. This study demonstrated that the PWB measures evaluated here are psychometrically sound, and suitable to be used in the South African context.

Keywords: psychological well-being; validity; test-retest; reliability; hope; faith; self-efficacy; general life satisfaction.

\section{Introduction}

Mental health and substance use disorders as well as injury account for a significant proportion of disability worldwide - especially in low-to-middle income countries (LMICs) such as South Africa (Collaborators \& Ärnlöv, 2020; WHO, 2017). In many developing countries, mental healthcare services are often absent or inadequate (Jansen et al., 2015). As a consequence, people who live in community settings with complex social problems often have to find their own way of coping with distress, build strength capacities, cultivate resilience and give meaning to their experiences (GilRivas, Handrup, Tanner, \& Walker, 2019; Jansen et al., 2015; Sankoh, Sevalie, \& Weston, 2018). The World Health Organization (WHO) as cited by Masten and Reed (2002) defines mental health as:

A state of well-being in which the individual realises his or her abilities, can cope with normal stresses of life, can work productively and fruitfully, and can contribute positively to their community. (Masten \& Reed, 2002, p. 90; WHO 2001a, b)

Therefore, suggesting the necessity of conceptualising and characterising the quality of life indicators, as well as psychosocial strategies to promote mental well-being. This is particularly important for South Africa because even though it is an upper-middle-income country, people still face huge socioeconomic, structural, and public health issues that tax their emotional resources. There are high levels of unemployment; in the last quarter of 2019 alone $27.6 \%$ people of productive age were without jobs. Crime is also on the rise in urban areas; between 2016 and 2017, 1.6 million individuals experienced contact crime such as murder, robbery and sexual offences, and a huge part of the population lives in overcrowded neighbourhoods with poor infrastructure, which make it difficult to monitor crime (Statistics South Africa, 2019).

Well-being classifies into two dimensions, namely subjective well-being (SWB), and psychological wellbeing (PWB) (Ryan, Huta, \& Deci, 2008; Smith \& Yang, 2017; Van de Weijer, Baselmans, Van der Deijl,

How to cite this article: Mpondo, F., Wray, C., Norris, S.A., Stein, A.D., Stein, A., \& Richter, L.M. (2021). Assessing psychological well-being measures among South African adults in the birth to twenty plus cohort. African Journal of Psychological Assessment, 3(0), a44. https:// doi.org/10.4102/ajopa.v3i0.44

Copyright: @ 2021 . The Authors. Licensee: AOSIS. This work is licensed under the Creative Commons Attribution License. 
\& Bartels, 2018). Subjective well-being can be operationalised with constructs that measure affect as well as those that cover cognitive aspects for example, Harmony in Life Scale (Nima, Cloninger, Persson, Sikström, \& Garcia, 2020). Psychological well-being refers to measures that assess efficacious or nonefficacious functioning at inter- and intra-individual levels, and is operationalised through constructs such as personal growth, purpose in life and self-acceptance (Ryff, 2014).

In this article, we evaluate specific domains of the National Institutes of Health (NIH) Toolbox Emotion Battery (Salsman et al., 2013) namely, hope, faith, social support, general selfefficacy, and life satisfaction which are measures of PWB. These PWB scales were selected because they are widely used in the South African public health and community research contexts (Brinker \& Cheruvu, 2017; Pacico, Bastianello, Zanon, \& Hutz, 2013; Van Zyl \& Dhurup, 2018). It is important to re-evaluate the psychometric properties of these validated scales, especially in a local context, to see how a particular measurement theory is reflected in local empirical data (Flora \& Flake, 2017). There is paucity of psychometric data on PWB scales in South Africa, which makes it difficult to tell whether the scales are measuring latent constructs per the original design.

Hope is considered a psychological strength used to ensure that goals are attained through planning, overcoming behavioural or physical health issues, and dealing with any unintended outcomes from stressful life events (Pacico et al., 2013; Savahl, Casas, \& Adams, 2016). Faith has been defined as how an individual understands their 'ultimate reality' (Fowler, 1981) by putting confidence in a higher power or being pious (Bai, Lazenby, Jeon, Dixon, \& McCorkle, 2015). The faith construct has been shown to have positive associations with physical and mental health as well as other measures such as coping, and self-esteem (Abdel-Khalek \& Tekke, 2019). Social support has been shown to buffer adverse life events through the action of others and belief of support, which leads to an appraisal of life situations as non-threatening. Social support is widely incorporated into interventions and used to explain behaviour change (Cohen, 2004). Many types of social support were evaluated and shown to be consistent; for example in relationships and risky behaviours, and in promoting physical activity (Brinker \& Cheruvu, 2017; Cohen, 2004; Ory et al., 2018; Simoni, Frick, \& Huang, 2006; Wright, 2016). Self-efficacy is the belief that one can accomplish tasks and goals in unpredictable circumstances. Efficacious individuals welcome challenging tasks as motivating factors, while inefficacious individuals dwell on their weaknesses (Bandura, 1986; Mpondo et al., 2015). Selfefficacy has been used extensively in health promotion studies and interventions (Dennis, Brennenstuhl, \& AbbassDick, 2018; Ory et al., 2018). General life satisfaction is an individual's judgement of the consonance of their living conditions and standards without comparing themselves to others (Diener, Emmons, Larsen, \& Griffin, 1985). According to Veenhoven (1993, p. 213), 'general life satisfaction is the degree to which a person evaluates their life'. Recent studies have looked at general life satisfaction in association with self-rated health and social capital constructs (Gigantesco et al., 2019; Maass, Kloeckner, Lindstrøm, \& Lillefjell, 2016).

The objective of this study was to assess the psychometric properties of PWB measures in the context of urban South Africa. We conducted exploratory factor analyses (EFAs) to evaluate structure patterns, and confirmatory factor analysis (CFA) to get fit indices. We checked for internal consistencies using Cronbach's alpha and scale validity by calculating correlations between all the scales, and we also conducted test-retest reliability as well as intraclass correlations (ICCs).

\section{Methods \\ Sampling}

The Birth to Twenty Plus (BT20+) cohort was established to observe growth, development and health of children and adolescents in an urban cohort, following the democratic transition in the Republic of South Africa. The cohort enrolled 3273 singleton babies from Soweto and Johannesburg, South Africa, who were born between 23 April and 8 June 1990, and who continued to live in the area for the first 6 months of the child's life. Since birth, information on socioeconomic, family and personal factors influencing physical and psychological health and wellbeing has been collected 21 times. This article uses data collected when cohort members were 28 years old. A detailed description of the study and its cohort is published elsewhere (Richter, Norris, Pettifor, Yach, \& Cameron, 2007). Data used here were collected between June 2018 and June 2019 from 1327 individuals, who had data on all the measures.

We collected test-retest reliability data from a sub-set of the cohort $(n=43)$ participants, who were seen at three time points (T1, T2 and T3). The average $\mathrm{T} 1-\mathrm{T} 2$ time point interval was 57 days, T2 - T3 was 14 days, and T1 - T3 was 191 days. Participants completed the same questionnaires and were seen by the same assessor at each time point.

\section{Measures}

All measures come from the NIH Toolbox Emotion battery, which identified and developed measures suitable for use in epidemiology research across different ethnicities and cultures in high income countries (Salsman et al., 2013).

Hope was measured using the WHO Quality of Life assessment (WHOQOL) study (Group, 1998). The scale comprises four Likert scale items with answer options ranging from 1 (not at all) to 5 (extremely). These items were shown to have good psychometric properties, that is, coefficient alpha of 0.74 in the original WHOQOL study (Group, 1998) under the psychological facet- spirituality domain. 
Faith was also measured using the WHOQOL assessment (Group, 1998). The scale comprises four Likert scale items with answer options ranging from 1 (not at all) to 5 (extremely). This measure had good psychometric properties that is, coefficient alpha of 0.74 in the WHOQOL validation study (Group, 1998) under the psychological facet- spirituality domain.

Social support was measured using the NIH Toolbox Social Support questionnaire (Salsman et al., 2013). This scale comprises eight self-report items with response options ranging from 1 (never) to 5 (always). These items have been shown to have a good model fit (i.e., $\mathrm{CFI}=0.99$; root mean square error of approximation [RMSEA] $=0.112$ ) and excellent psychometric properties (i.e. coefficient alpha 0.96) in the NIH Toolbox validation study (Salsman et al., 2013).

Life satisfaction was measured using the NIH Toolbox Life Satisfaction Scale (Salsman et al., 2013), which comprises five Likert scale items, with response options ranging from 1 (strongly disagree) to 5 (strongly agree). The psychometric properties of the scale in the NIH Toolbox validation study were good (i.e. coefficient alphas of 0.79-0.89; Salsman et al., 2013).

Self-efficacy was measured using the NIH Toolbox general Self-Efficacy Scale, which comprises nine items with response options ranging from 1 (never) to 5 (very often). This scale has been shown to have excellent psychometric properties (i.e., coefficient alphas of 0.93; CFI $=0.99$ and RMSEA = 0.73; Salsman et al., 2013).

\section{Analysis}

A total sample of 1327 participants was used to conduct EFAs to evaluate the factor structure patterns of the hope, faith, social support, general life satisfaction and self-efficacy measures. We used the Keiser Meyer Olkin-Bartlett's (KMO) test for sampling adequacy: KMO values between 0.8 and 1 indicate sampling adequacy, values $<0.6$ indicate inadequacy of the sample, and KMO values close to zero indicate widespread correlation. To understand the structure of variable clusters and identify latent variables we used the principal factor (pf) estimation technique. We also used the estat anti command to check for variables that were correlating too high. We chose oblique oblimin rotation to get the simplest factor structure. To extract factors, we used Kaiser's criterion by checking the scree plots. Factors with loadings 0.30 or higher were considered components of one domain; at least three items needed to load onto a domain to be considered a valid factor. To obtain fit indices we conducted CFA using maximum likelihood (ML) estimation, and default bootstrap settings. Fit indices calculated were: chi-square $\left(\chi^{2}\right)$, chi-square/degree of freedom ration $\left(\chi^{2} / d f\right)$, the comparative fit index (CFI; Hu \& Bentler, 1999), the Tucker-Lewis index (TLI: Hu \& Bentler, 1999), the RMSEA (Steiger, 1990), and a standardised root mean square residual (SRMR; Hu \& Bentler, 1999). Best practice guidelines suggest that $\chi^{2} / d f$ should be less than 5, SRMR should be close to zero, RMSEA should be $<0.05$, thus indicating a good fit, whereas a value that is $<0.08$ indicates a reasonable model, and values exceeding that indicate a mediocre or a poor fit (Byrne, 2010). For a good fit, the CFI and TLI are recommended to be $\geq 0.90$ (Byrne, 2010; Hu \& Bentler, 1999). Internal consistency and reliability were determined using Cronbach's alpha $(\alpha)$. To determine scale validity, we used Pearson's correlation matrix. STATA version 14 was used for analysis (StataCorp, 2015).

For the test-retest reliability, we evaluated practice effects using $t$-tests and effect sizes. Cohen's $d$ was used to determine the magnitude of the practice effects, 0.2 is interpreted as a small effect, 0.5 as moderate and 0.8 as a large effect (Cohen, 2004). We also used ICCs to determine test-retest reliability. Intra-class correlation coefficients were interpreted as: poor $(<0.5)$, moderate $(0.50-0.74)$, good (0.75-0.90) and above 0.90 as excellent test-retest reliability (Koo \& Li, 2016).

\section{Ethical considerations}

The Human Research Ethics Committee of University of the Witwatersrand (South Africa) granted ethical clearance for this study (reference number: M180225) and the study was conducted in line with the Principles of the Declaration of Helsinki for research involving human subjects. Participants provided written informed assent consent.

\section{Results}

A total of 1327 participants were interviewed, and about $99 \%$ of those had complete data for variables of interest. About $639(48 \%)$ were male and 698 (52\%) females. Results of normality are presented in Table 1 and item means for the PWB measures stratified by sex are presented in Table 2.

\section{Factor analysis}

All measures had KMO test values between 0.8 and 1, and thus suitable for further factor analysis. The scree plots showed that all latent variables converged into a single higher-order factor: eigenvalues $>1$. Table 3 displays exploratory factor analysis (EFA) results. Factors were regarded as stable if at least three items had significant loadings; this was the case for all measures.

The CFA results are presented in Table 4. For the Hope scale the unadjusted model fit was poor that is, RMSEA = 0.13 ; CFI $=0.60$, and TLI $=0.82$. We identified items that may have been ambiguous or may have had an unclear meaning to the participant and lower factor loadings that

TABLE 1: Tests of normality for psychological well-being measures.

\begin{tabular}{lcc}
\hline Measure & Skewness (range) & Kurtosis (range) \\
\hline Hope & $-0.15--0.38$ & $2.60-2.91$ \\
Faith & $-0.26--0.42$ & $2.82-3.01$ \\
Social support & $-0.20--0.35$ & $2.50-2.81$ \\
General life satisfaction & $-0.58--1.19$ & $3.11-7.77$ \\
Self-efficacy & $0.05-0.22$ & $1.64-2.05$ \\
\hline
\end{tabular}


TABLE 2: Mean and standard deviation by gender of item scores of socioemotional measures $(n=1327)$

\begin{tabular}{|c|c|c|c|c|c|}
\hline \multirow[t]{2}{*}{ Measure } & \multirow[t]{2}{*}{ Items } & \multicolumn{2}{|c|}{ Male } & \multicolumn{2}{|c|}{ Female } \\
\hline & & Mean & SD & Mean & SD \\
\hline \multirow[t]{4}{*}{ Hope } & How hopeful do you feel & 3.65 & 1.00 & 3.75 & 1.07 \\
\hline & $\begin{array}{l}\text { To what extent are you hopeful } \\
\text { about life }\end{array}$ & 3.90 & 0.94 & 4.00 & 0.97 \\
\hline & $\begin{array}{l}\text { To what extent does being optimistic } \\
\text { improve your quality of life }\end{array}$ & 3.77 & 0.94 & 3.74 & 1.01 \\
\hline & $\begin{array}{l}\text { How optimistic are you able to } \\
\text { remain in times of uncertainty }\end{array}$ & 3.22 & 0.92 & 3.23 & 1.02 \\
\hline \multirow[t]{4}{*}{ Faith } & $\begin{array}{l}\text { To what extent does faith give you } \\
\text { comfort in daily life }\end{array}$ & 4.02 & 0.99 & 3.78 & 1.15 \\
\hline & $\begin{array}{l}\text { To what extent does faith give you } \\
\text { strength in daily life }\end{array}$ & 4.04 & 0.97 & 3.83 & 1.09 \\
\hline & $\begin{array}{l}\text { To what extent does faith help you } \\
\text { enjoy life }\end{array}$ & 4.08 & 0.96 & 3.83 & 1.10 \\
\hline & $\begin{array}{l}\text { To what extent do you have strong } \\
\text { personal beliefs }\end{array}$ & 4.02 & 0.95 & 3.84 & 1.02 \\
\hline \multirow[t]{9}{*}{$\begin{array}{l}\text { Social } \\
\text { support }\end{array}$} & $\begin{array}{l}\text { In the past month please describe } \\
\text { how often you had someone, or }\end{array}$ & & & & \\
\hline & Who understand your problem & 3.32 & 1.23 & 3.66 & 1.25 \\
\hline & $\begin{array}{l}\text { Who would listen to you when you } \\
\text { needed to talk }\end{array}$ & 3.98 & 1.10 & 3.67 & 1.19 \\
\hline & $\begin{array}{l}\text { Felt there were people to talk to if } \\
\text { you were upset }\end{array}$ & 3.83 & 1.23 & 3.43 & 1.29 \\
\hline & To talk to when you had a bad day & 3.93 & 1.20 & 3.47 & 1.32 \\
\hline & To talk with about your problems & 3.97 & 1.20 & 3.53 & 1.37 \\
\hline & $\begin{array}{l}\text { You trust to talk to about your } \\
\text { feelings }\end{array}$ & 3.88 & 1.21 & 3.47 & 1.39 \\
\hline & $\begin{array}{l}\text { Could get helpful advice from others } \\
\text { when dealing with a problem }\end{array}$ & 3.76 & 1.14 & 3.50 & 1.18 \\
\hline & $\begin{array}{l}\text { To turn to for suggestions about how } \\
\text { to deal with a problem }\end{array}$ & 3.80 & 1.18 & 3.54 & 1.20 \\
\hline \multirow{5}{*}{$\begin{array}{l}\text { General life } \\
\text { satisfaction }\end{array}$} & Your life is going well & 3.57 & 0.96 & 3.53 & 0.95 \\
\hline & Your life is just right & 3.64 & 0.87 & 3.57 & 0.92 \\
\hline & You wish you had a different kind of life & 3.01 & 1.39 & 2.98 & 1.37 \\
\hline & You have a good life & 3.66 & 0.89 & 3.60 & 0.89 \\
\hline & You have what you want in life & 2.85 & 1.09 & 2.89 & 1.05 \\
\hline \multirow[t]{9}{*}{ Self-efficacy } & $\begin{array}{l}\text { You can manage to solve difficult if } \\
\text { you try hard enough }\end{array}$ & 2.99 & 0.88 & 2.92 & 0.88 \\
\hline & $\begin{array}{l}\text { It is easy for you to stick to your aims } \\
\text { and accomplish your goals }\end{array}$ & 2.74 & 0.89 & 2.68 & 0.87 \\
\hline & $\begin{array}{l}\text { You are confident that you can deal } \\
\text { efficiently with unexpected events }\end{array}$ & 2.77 & 0.89 & 2.87 & 0.85 \\
\hline & $\begin{array}{l}\text { Thanks to your talents and skills, you } \\
\text { know how to handle unexpected } \\
\text { situations }\end{array}$ & 3.01 & 0.33 & 2.85 & 0.31 \\
\hline & $\begin{array}{l}\text { You can solve most problems if you } \\
\text { try hard enough }\end{array}$ & 3.10 & 0.81 & 3.00 & 0.85 \\
\hline & $\begin{array}{l}\text { You stay calm when facing difficulties } \\
\text { because you can handle them }\end{array}$ & 2.80 & 0.91 & 2.66 & 0.92 \\
\hline & $\begin{array}{l}\text { When you have a problem, you can } \\
\text { find several ways to solve it }\end{array}$ & 2.85 & 0.86 & 2.75 & 0.88 \\
\hline & $\begin{array}{l}\text { If you are in trouble, you can think of } \\
\text { a solution }\end{array}$ & 3.00 & 0.87 & 2.82 & 0.85 \\
\hline & $\begin{array}{l}\text { You can handle whatever comes } \\
\text { your way }\end{array}$ & 2.92 & 0.88 & 2.89 & 0.86 \\
\hline
\end{tabular}

SD, standard devation.

is, Hope-item 4 'How optimistic are you to remain in times of uncertainty'. For the Faith measure, the unadjusted model had estimates: $\mathrm{RMSEA}=0.09 ; \mathrm{CFI}=0.80$ and TLI $=$ 0.82 , and we removed item 4 'To what extent does faith help you enjoy your life'. The Social Support scale also had poor fit indices (RMSEA $=0.13 ; \mathrm{CFI}=0.64$ and $\mathrm{TLI}=0.81$ ), therefore two items were removed: item 6 'In the past month, please describe how often you had someone you trust to talk with about your feelings', and item 8 'In the past month, please describe how often you had someone to turn to for suggestions about how to deal with a problem'.
TABLE 3: Exploratory factor analyses and Keiser-Meyer-Olkin test for sampling suitability $(n=1327)$

\begin{tabular}{|c|c|c|c|}
\hline Measure & Items & $\begin{array}{l}\text { Factor } \\
\text { loading }\end{array}$ & KMO \\
\hline \multirow[t]{4}{*}{ Hope } & How hopeful do you feel & 0.77 & 0.74 \\
\hline & To what extent are you hopeful about life & 0.78 & 0.73 \\
\hline & $\begin{array}{l}\text { To what extent does being optimistic improve } \\
\text { your quality of life }\end{array}$ & 0.77 & 0.75 \\
\hline & $\begin{array}{l}\text { How optimistic are you able to remain in times of } \\
\text { uncertainty }\end{array}$ & 0.74 & 0.76 \\
\hline \multirow[t]{4}{*}{ Faith } & $\begin{array}{l}\text { To what extent does faith give you comfort in } \\
\text { daily life }\end{array}$ & 0.84 & 0.88 \\
\hline & $\begin{array}{l}\text { To what extent does faith give you strength in } \\
\text { daily life }\end{array}$ & 0.90 & 0.82 \\
\hline & To what extent does faith help you enjoy life & 0.90 & 0.81 \\
\hline & $\begin{array}{l}\text { To what extent do you have strong personal } \\
\text { beliefs }\end{array}$ & 0.87 & 0.85 \\
\hline \multirow[t]{9}{*}{$\begin{array}{l}\text { Social } \\
\text { support }\end{array}$} & $\begin{array}{l}\text { In the past month please describe how often you } \\
\text { had someone, or }\end{array}$ & & \\
\hline & Who understand your problem & 0.71 & 0.93 \\
\hline & $\begin{array}{l}\text { Who would listen to you when you needed } \\
\text { to talk }\end{array}$ & 0.79 & 0.92 \\
\hline & $\begin{array}{l}\text { Felt there were people to talk to if you were } \\
\text { upset }\end{array}$ & 0.79 & 0.94 \\
\hline & To talk to when you had a bad day & 0.80 & 0.94 \\
\hline & To talk with about your problems & 0.83 & 0.89 \\
\hline & You trust to talk to about your feelings & 0.81 & 0.90 \\
\hline & $\begin{array}{l}\text { Could get helpful advice from others when } \\
\text { dealing with a problem }\end{array}$ & 0.77 & 0.88 \\
\hline & $\begin{array}{l}\text { Had someone to turn to for suggestions about } \\
\text { how to deal with a problem }\end{array}$ & 0.79 & 0.88 \\
\hline \multirow{5}{*}{$\begin{array}{l}\text { General life } \\
\text { satisfaction }\end{array}$} & Your life is going well & 0.82 & 0.78 \\
\hline & Your life is just right & 0.70 & 0.81 \\
\hline & You wish you had a different kind of life & 0.61 & 0.84 \\
\hline & You have a good life & 0.80 & 0.80 \\
\hline & You have what you want in life & 0.75 & 0.82 \\
\hline \multirow[t]{9}{*}{ Self-efficacy } & $\begin{array}{l}\text { You can manage to solve difficult if you try hard } \\
\text { enough }\end{array}$ & 0.72 & 0.87 \\
\hline & $\begin{array}{l}\text { It is easy for you to stick to your aims and } \\
\text { accomplish your goals }\end{array}$ & 0.65 & 0.92 \\
\hline & $\begin{array}{l}\text { You are confident that you can deal efficiently } \\
\text { with unexpected events }\end{array}$ & 0.70 & 0.90 \\
\hline & $\begin{array}{l}\text { Thanks to your talents and skills, you know how } \\
\text { to handle unexpected situations }\end{array}$ & 0.71 & 0.90 \\
\hline & $\begin{array}{l}\text { You can solve most problems if you try hard } \\
\text { enough }\end{array}$ & 0.72 & 0.88 \\
\hline & $\begin{array}{l}\text { You stay calm when facing difficulties because } \\
\text { you can handle them }\end{array}$ & 0.63 & 0.92 \\
\hline & $\begin{array}{l}\text { When you have a problem, you can find several } \\
\text { ways to solve it }\end{array}$ & 0.75 & 0.89 \\
\hline & If you are in trouble, you can think of a solution & 0.71 & 0.90 \\
\hline & You can handle whatever comes your way & 0.75 & 0.90 \\
\hline
\end{tabular}

KMO, Keiser-Meyer-Olkin.

\section{Scale consistency and validity}

The mean and standard deviations of the summed scores of all the measures are presented in Table 4 . The individual scales for Hope, Faith, Social Support, General Life Satisfaction, and Self-Efficacy produced high internal consistencies ( $\alpha$ 's). General Life Satisfaction and Hope showed $\alpha$ 's > 0.70; Faith, Social Support and Self-Efficacy $\alpha>0.80$ (Figure 1.).

The Pearson correlation coefficients are presented in Table 5. Most of the correlations showed significant positive associations of medium magnitudes, and Faith vs. Hope and Self-Efficacy vs. Hope showed strong correlations.

\section{Test-retest}

We assessed participants at three-time points: T1 and T2, and each had 43 participants, and T3, which had 30 
TABLE 4: Confirmatory factor analysis for fit indices.

\begin{tabular}{|c|c|c|c|c|c|c|c|c|c|c|}
\hline Model & $\begin{array}{l}\text { Number of } \\
\text { items }\end{array}$ & YB-X $X^{2}$ & RMSEA & SRMR & CFI & TLI & $\begin{array}{l}\text { Inter-item } \\
\text { covariance }\end{array}$ & $\mathbf{N}$ & Mean & $\begin{array}{l}\text { Standard } \\
\text { deviation }\end{array}$ \\
\hline Hope & 3 & 0.00 & 0.00 & 0.00 & 1.00 & 1.00 & 0.56 & 1327 & 3.86 & 0.99 \\
\hline Faith & 3 & 0.00 & 0.00 & 0.00 & 1.00 & 1.00 & 0.65 & 1326 & 3.94 & 0.94 \\
\hline Social support & 6 & 65.17 & 0.06 & 0.02 & 0.98 & 0.97 & 0.89 & 1327 & 3.68 & 0.99 \\
\hline General life satisfaction & 5 & 43.77 & 0.04 & 0.01 & 0.99 & 0.98 & 0.33 & 1327 & 3.33 & 0.76 \\
\hline Self-efficacy & 9 & 171.71 & 0.07 & 0.03 & 0.95 & 0.94 & 0.35 & 1327 & 2.86 & 0.61 \\
\hline
\end{tabular}

YB-X², Yuan-Bentler chi-square; RMSEA, root mean square error of approximation; SRMR, standardised root mean square residual; CFI, comparative fit index; TLI, Tucker-Lewis index.

TABLE 5: Correlation of all socio-emotional measures.

\begin{tabular}{lccccc}
\hline Measure & Hope & Faith & $\begin{array}{c}\text { Social } \\
\text { support }\end{array}$ & $\begin{array}{c}\text { General life } \\
\text { satisfaction }\end{array}$ & Self-efficacy \\
\hline Hope & - & - & - & - & - \\
Faith & $0.49^{*}$ & - & - & - & - \\
Social support & $0.33^{*}$ & $0.27^{*}$ & - & - & - \\
$\begin{array}{l}\text { General life } \\
\text { satisfaction }\end{array}$ & $0.36^{*}$ & $0.22^{*}$ & $0.29 *$ & - & - \\
Self-efficacy & $0.47^{*}$ & $0.32^{*}$ & $0.30^{*}$ & $0.34^{*}$ & - \\
\hline$*, p<0.01$ & & & & &
\end{tabular}

$*, p<0.01$.

TABLE 6: Test-retest mean assessment scores over time.

\begin{tabular}{|c|c|c|c|c|c|c|c|c|c|c|}
\hline \multirow[t]{2}{*}{ Measure } & \multicolumn{2}{|c|}{$\mathrm{T} 1(N=43)$} & \multicolumn{2}{|c|}{$\mathrm{T} 2(N=43)$} & \multicolumn{2}{|c|}{ T3 $(N=30)$} & \multirow{2}{*}{$\begin{array}{l}\text { Time } \\
\text { point }\end{array}$} & \multirow[t]{2}{*}{$t$} & \multirow[t]{2}{*}{$p$} & \multirow[t]{2}{*}{$d$} \\
\hline & Mean & SD & Mean & SD & Mean & SD & & & & \\
\hline \multirow[t]{2}{*}{ Hope } & 3.66 & 0.82 & 3.71 & 0.86 & 3.69 & 0.90 & $\mathrm{~T} 1-\mathrm{T} 2$ & 0.27 & 0.39 & 0.51 \\
\hline & & & & & & & $\mathrm{T} 2-\mathrm{T} 3$ & 0.14 & 0.55 & 0.30 \\
\hline \multirow[t]{2}{*}{ Faith } & 3.86 & 0.86 & 4.01 & 0.73 & 3.95 & 0.91 & $\mathrm{~T} 1-\mathrm{T} 2$ & 0.20 & 0.84 & 0.15 \\
\hline & & & & & & & $\mathrm{T} 2-\mathrm{T} 3$ & 0.35 & 0.36 & 0.06 \\
\hline \multirow{2}{*}{$\begin{array}{l}\text { Social } \\
\text { support }\end{array}$} & 3.30 & 1.06 & 3.44 & 1.11 & 3.72 & 1.11 & $\mathrm{~T} 1-\mathrm{T} 2$ & 0.12 & 0.44 & 0.03 \\
\hline & & & & & & & $\mathrm{T} 2-\mathrm{T} 3$ & 0.83 & 0.20 & 0.21 \\
\hline \multirow{2}{*}{$\begin{array}{l}\text { General life } \\
\text { satisfaction }\end{array}$} & 2.00 & 0.85 & 2.03 & 0.80 & 2.35 & 0.79 & $\mathrm{~T} 1-\mathrm{T} 2$ & 1.07 & 0.14 & 0.14 \\
\hline & & & & & & & $\mathrm{T} 2-\mathrm{T} 3$ & 2.46 & $0.00^{* *}$ & 0.32 \\
\hline \multirow[t]{2}{*}{ Self-efficacy } & 3.54 & 0.79 & 3.82 & 0.62 & 4.00 & 0.87 & $\mathrm{~T} 1-\mathrm{T} 2$ & 1.75 & $0.04^{*}$ & 0.28 \\
\hline & & & & & & & $\mathrm{T} 2-\mathrm{T} 3$ & 0.43 & 0.33 & 0.70 \\
\hline
\end{tabular}

$\mathrm{SD}$, standard deviation.

$*, p<0.05, * *, p<0.01$.

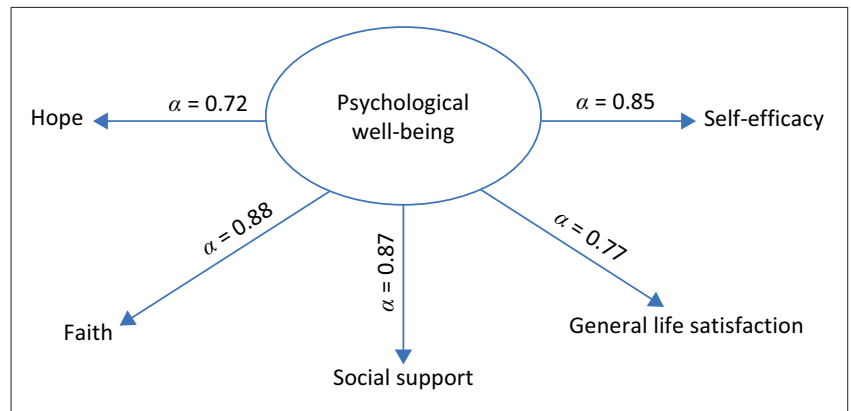

FIGURE 1: Reliability scores $(\alpha)$ of each socio-emotional measure $\alpha$.

participants (see Table 6 for means and SD at each time point). At time point T1 to T2, Self-Efficacy showed significant practice effects with a small magnitude, Hope had moderate non-significant practice effects. All other practice effects at T1 and T2 were small and non-significant. At T2 and T3, General Life Satisfaction had small and significant effects, Self-Efficacy had large non-significant effects, and all other measures had small non-significant effects.

Table 7 depicts ICC test-retest reliability estimates. At timepoint $\mathrm{T} 1$ to $\mathrm{T} 2$, the reliability estimate was moderate for all PWB measures. At timepoint T2 to T3, the reliability estimates for Hope, General Life Satisfaction, and Self-Efficacy were moderate, whereas Faith and Social Support showed good reliability.

\section{Discussion}

This article aimed to evaluate the psychometric properties of PWB measures: Hope, Faith, Social Support, Self-Efficacy, and General Life Satisfaction, in a sample of young adult urban South Africans. The factor structures for all the measures were unidimensional similar to other studies (De Maria, Vellone, Durante, Biagioli, \& Matarese, 2018; Hinz et al., 2018; Nel \& Boshoff, 2014; Salsman et al., 2013). We removed some items in our CFA to improve fit indices (for Hope, Faith, and Social Support). This suggests that the language of the removed items needs to be re-evaluated to ensure acceptability to local understandings. The correlations allowed comparison of the magnitude of associations between the measures; Faith, Hope, Self-Efficacy, and General Life Satisfaction were shown to be valid as confirmed by good Cronbach's alphas (Westen \& Rosenthal, 2003). This result suggests future studies can potentially assess these measures together. The test-retest results showed small practice effects for Self-Efficacy and General Life Satisfaction to some extent expected given the relatively short period of time between test-retest intervals. This was expected as participants had become familiar with the measures. Intraclass correlations were moderate at T1 - T2 for all the measures, and for Faith the ICC was good, as well as for Social Support at T2 - T3 thus implying that there were small variations that originated from the instruments or circumstances under which measurements were taken. This suggests that the measures were reliable for application in the South African context (De Vet, Terwee, Knol, \& Bouter, 2006; Koo \& Li, 2016).

Participants reported moderate to high levels of Hope, Faith, Social Support and General Life Satisfaction, and low to moderate levels of Self-efficacy. Because these measures have been shown to have buffering effect against mental health disorders, and to enhance one's reserves of social cognitive and problem-solving capabilities, they can be targeted for mental health promotion interventions (Nyqvist, Forsman, Giuntoli, \& Cattan, 2013). The interventions can be delivered in various ways by community healthcare workers who would use a community-based model or through using digital technology (e.g. zero-rated platforms on cellular phones). The interventions could teach people how to cultivate positive feelings, exercise cognitive flexibility, self-compassion, have hope and optimism while providing and using support resources intentionally. 
TABLE 7: Intraclass correlation coefficient for test-retest measures.

\begin{tabular}{|c|c|c|c|c|c|c|c|c|c|c|}
\hline Timepoint & Hope & $95 \% \mathrm{Cl}$ & Faith & $95 \% \mathrm{Cl}$ & Social support & $95 \% \mathrm{Cl}$ & $\begin{array}{c}\text { General } \\
\text { self-efficacy }\end{array}$ & $95 \% \mathrm{Cl}$ & $\begin{array}{l}\text { General life } \\
\text { satisfaction }\end{array}$ & $95 \% \mathrm{Cl}$ \\
\hline $\mathrm{T} 1-\mathrm{T} 2$ & 0.65 & $0.39-0.79$ & 0.57 & $0.25-0.75$ & 0.63 & $0.36-0.78$ & 0.61 & $0.31-0.77$ & 0.69 & $0.46-0.82$ \\
\hline $\mathrm{T} 2-\mathrm{T} 3$ & 0.61 & $0.26-0.80$ & 0.83 & $0.68-0.91$ & 0.77 & $0.56-0.88$ & 0.67 & $0.36-0.82$ & 0.54 & $0.12-0.76$ \\
\hline
\end{tabular}

Note: Intraclass correlation coefficient (ICC): $<0.50$ poor; $0.50-0.74$ moderate; $0.75-0.90$ good and $>0.90$ excellent.

$\mathrm{Cl}$, confidence interval.

Another study conducted on coping in the Soweto population showed that religious activity (i.e. gathering for prayer in a group or praying) was perceived to be a good source of resilience and coping (Kim, Kaiser, Bosire, Shahbazian, \& Mendenhall, 2019). This is a pre-existing psychosocial resource that can be incorporated into interventions, not to endorse religion per se, in the organisational sense, but to use some of the tenets embodied therein such as altruism, forgiveness, gratitude and social support as tools to buffer against mental health issues (Sharma \& Singh, 2019).

The limitation of this study pertains to the generalisability of some of the measures (Hope, Faith and Social Support) because some items were removed to improve fit indices and indeed reliability. It may be difficult to compare our findings to other validated studies. However, the removal of the items was in line with the purpose of testing the psychometric properties of a scale in a local context. Removing items is warranted when those items have weak loadings or are ambiguous - concerning how a participant interacts with an item (i.e. obscure, sophisticated or complex vocabulary). Literature shows that the removal of items from a scale does not compromise the reliability of that scale (McCrae, Kurtz, Yamagata, \& Terracciano, 2011). Another limitation is the sample size used for the test-retest: it too might affect the generalisability of the results. Because of time constraints we could not collect repeat measures for the PWB scales for a bigger sample.

\section{Conclusion}

In conclusion, the fact that all PWB measures were shown to have high internal consistency, validity and reliability when used within an urban and multi-cultural context is a strength and points to their usefulness of the tools for assessing whether individuals are languishing or thriving. Therefore, the measures are relevant for the community and/or research setting to be administered by trained non-clinical assessors.

\section{Acknowledgements}

Our gratitude goes to all the participants of the Birth-to-Twenty Plus cohort, their parents and 298 relatives for contributing for more than 27 years to this study.

\section{Competing interests}

The authors declare that they have no financial or personal relationships that may have inappropriately influenced them in writing this article.

\section{Authors' contributions}

All authors conceived and/or designed the work that led to the submission, revised the manuscript, approved the final version, agreed to be accountable for all aspects of the work. F.M. and L.M.R. carried out the data analyses and interpreted the data. F.M., C.W. and L.M.R. carried out the writing of the manuscript. S.A.N., A.D.S., and A.S. made significant contributions in interpreting the results and revising the manuscript.

\section{Funding information}

The study was funded by the Bill and Melinda Gates Foundation (OPP1164115).

\section{Data availability}

Data is under an embargo from the date of data collection (September 2019) until June 2021, thereafter the data will be made freely available; hyperlinks will be published. The data that support the findings of this study are available from the corresponding author, F.M., upon reasonable request.

\section{Disclaimer}

The views and opinions expressed in this article are those of the authors and do not necessarily reflect the official policy or position of any affiliated agency of the authors.

\section{References}

Abdel-Khalek, A.M., \& Tekke, M. (2019). The association between religiosity, wellbeing, and mental health among college students from Malaysia. Revisto Mexicana de Psicología, 36(1), 5-16.

Bai, M., Lazenby, M., Jeon, S., Dixon, J., \& McCorkle, R. (2015). Exploring the relationship between spiritual well-being and quality of life among patients newly relationship between spiritual well-being and quality of life among patients newly
diagnosed with advanced cancer. Palliative \& Supportive Care, 13(4), 927-935. https://doi.org/10.1017/S1478951514000820

Bandura, A. (1986). The explanatory and predictive scope of self-efficacy theory. Journal of Social and Clinical Psychology, 4(3), 359-373. https://doi.org/10.1521/ jscp.1986.4.3.359

Brinker, J., \& Cheruvu, V.K. (2017). Social and emotional support as a protective factor against current depression among individuals with adverse childhood experiences. Preventive Medicine Reports, 5, 127-133. https://doi.org/10.1016/ j.pmedr.2016.11.018

Byrne, B.M. (2010). Structural equation modeling with AMOS Basic concepts, applications, and programming (Multivariate applications series). New York, NY: Routledge.

Cohen, S. (2004). Social relationships and health. American Psychologist, 59(8), 676 https://doi.org/10.1037/0003-066X.59.8.676

Collaborators, G.B.D., \& Ärnlöv, J. (2020). Global burden of 87 risk factors in 204 countries and territories, 1990-2019: A systematic analysis for the global burden of disease study 2019. The Lancet, 396(10258), 1223-1249. https://doi. org/10.1016/S0140-6736(20)30752-2

De Maria, M., Vellone, E., Durante, A., Biagioli, V., \& Matarese, M. (2018). Psychometrics evaluation of the multidimensional scale of perceived social support (MSPSS) in people with chronic disease. Annali Dell'Istituto Superiore D Sanità, 54(4), 308-315.

Dennis, C.-L., Brennenstuhl, S., \& Abbass-Dick, J. (2018). Measuring paternal breastfeeding self-efficacy: A psychometric evaluation of the breastfeeding selfefficacy scale-short form among fathers. Midwifery, 64, 17-22. https://doi. org/10.1016/j.midw.2018.05.005

De Vet, H.C.W., Terwee, C.B., Knol, D.L., \& Bouter, L.M. (2006). When to use agreement versus reliability measures. Journal of Clinical Epidemiology, 59(10), 1033-1039. https://doi.org/10.1016/j.jclinepi.2005.10.015

Diener, E.D., Emmons, R.A., Larsen, R.J., \& Griffin, S. (1985). The satisfaction with life scale. Journal of Personality Assessment, 49(1), 71-75. https://doi.org/10.1207/ s15327752jpa4901_13 
Flora, D.B., \& Flake, J.K. (2017). The purpose and practice of exploratory and confirmatory factor analysis in psychological research: Decisions for scale development and validation. Canadian Journal of Behavioural Science/Revue Canadienne Des Sciences Du Comportement, 49(2), 78. https://doi.org/10.1037/ Canadienne
cbs0000069

Fowler, J.W. (1981). Faith and human development. New York, NY: Harper \& Row.

Gigantesco, A., Fagnani, C., Toccaceli, V., Stazi, M.A., Lucidi, F., Violani, C., ... Picardi, A. (2019). The relationship between satisfaction with life and depression symptoms by gender. Frontiers in Psychiatry, 10, 419. https://doi.org/10.3389/fpsyt.2019.00419

Gil-Rivas, V., Handrup, C.T., Tanner, E., \& Walker, D.K. (2019). Global mental health: A call to action. American Journal of Orthopsychiatry, 89(4), 420. https://doi. org/10.1037/ort0000373

Group, T.W. (1998). The world health organization quality of life assessment (WHOQOL): Development and general psychometric properties. Social Science \& Medicine, 46(12), 1569-1585. https://doi.org/10.1016/S0277-9536(98)00009-4

Hinz, A., Conrad, I., Schroeter, M.L., Glaesmer, H., Brähler, E., Zenger, M., ... Herzberg, P.Y. (2018). Psychometric properties of the satisfaction with life scale (SWLS), derived from a large German community sample. Quality of Life Research, 27(6), 1661-1670. https://doi.org/10.1007/s11136-018-1844-1

Hu, L., \& Bentler, P.M. (1999). Cutoff criteria for fit indexes in covariance structure analysis: Conventional criteria versus new alternatives. Structural Equation Modeling: A Multidisciplinary Journal, 6(1), 1-55. https://doi.org/10.1080/ 10705519909540118

Jansen, S., White, R., Hogwood, J., Jansen, A., Gishoma, D., Mukamana, D., \& Richters, A. (2015). The 'treatment gap' in global mental health reconsidered: Sociotherapy for collective trauma in Rwanda. European Journal of Psychotraumatology, 6(1), 28706. https://doi.org/10.3402/ejpt.v6.28706

Kim, A.W., Kaiser, B., Bosire, E., Shahbazian, K., \& Mendenhall, E. (2019). Idioms of resilience among cancer patients in urban South Africa: An anthropological heuristic for the study of culture and resilience. Transcultural Psychiatry, 56(4) 720-747. https://doi.org/10.1177/1363461519858798

Koo, T.K., \& Li, M.Y. (2016). A guideline of selecting and reporting intraclass correlation coefficients for reliability research. Journal of Chiropractic Medicine, 15(2), 155-163. https://doi.org/10.1016/j.jcm.2016.02.012

Maass, R., Kloeckner, C.A., Lindstrøm, B., \& Lillefjell, M. (2016). The impact of neighborhood social capital on life satisfaction and self-rated health: A possible pathway for health promotion? Health \& Place, 42, 120-128. https://doi. org/10.1016/j.healthplace.2016.09.011

Masten, A.S., \& Reed, M.-G.J. (2002). Resilience in development. In C.R. Snyder \& S.J. Lopez (Eds.), Handbook of positive psychology (pp. 74-88). Oxford: Oxford University Press.

McCrae, R.R., Kurtz, J.E., Yamagata, S., \& Terracciano, A. (2011). Internal consistency, retest reliability, and their implications for personality scale validity. Personality and Social Psychology Review : An Official Journal of the Society for Personality and SocialPsychology, 15(1),28-50.https://doi.org/10.1177/1088868310366253

Mpondo, F., Ruiter, R.A.C., Van den Borne, B., \& Reddy, P.S. (2015). Self-determination and gender-power relations as predictors of condom use self-efficacy among South African women. Health Psychology Open, 2(2), 1-11. https://doi. org/10.1177/2055102915598676

Nel, P., \& Boshoff, A. (2014). Factorial invariance of the adult state hope scale. SA Journa of Industrial Psychology, 4O(1), a1177. https://doi.org/10.4102/sajip.v40i1.1177

Nima, A.A., Cloninger, K.M., Persson, B.N., Sikström, S., \& Garcia, D. (2020). Validation of subjective well-being measures using item response theory. Frontiers in Psychology, 10, 3036. https://doi.org/10.3389/fpsyg.2019.03036

Nyqvist, F., Forsman, A.K., Giuntoli, G., \& Cattan, M. (2013). Social capital as a resource for mental well-being in older people: A systematic review. Aging \& Mental Health, 17(4), 394-410. https://doi.org/10.1080/13607863.2012.742490

Ory, M.G., Lee, S., Han, G., Towne, S.D., Quinn, C., Neher, T., ... Smith, M.L. (2018) Effectiveness of a lifestyle intervention on social support, self-efficacy, and physical activity among older adults: Evaluation of texercise select. International Journal of Environmental Research and Public Health, 15(2), 234. https://doi. org/10.3390/ijerph15020234
Pacico, J.C., Bastianello, M.R., Zanon, C., \& Hutz, C.S. (2013). Adaptation and validation of the dispositional hope scale for adolescents. Psicologia: Reflexão e Crítica, 26(3), 488-492. https://doi.org/10.1590/S0102-79722013000300008

Richter, L., Norris, S., Pettifor, J., Yach, D., \& Cameron, N. (2007). Cohort profile: Mandela's children: The 1990 birth to twenty study in South Africa. International Journal of Epidemiology, 36(3), 504-511. https://doi.org/10.1093/ije/dym016

Ryan, R.M., Huta, V., \& Deci, E.L. (2008). Living well: A self-determination theory perspective on eudaimonia. Journal of Happiness Studies, 9(1), 139-170. https:// doi.org/10.1007/s10902-006-9023-4

Ryff, C.D. (2014). Psychological well-being revisited: Advances in the science and practice of eudaimonia. Psychotherapy and Psychosomatics, 83(1), 10-28. https://doi.org/10.1159/000353263

Salsman, J.M., Butt, Z., Pilkonis, P.A., Cyranowski, J.M., Zill, N., Hendrie, H.C., ... Choi, S.W. (2013). Emotion assessment using the NIH Toolbox. Neurology, 80(Suppl 3) S76-S86. https://doi.org/10.1212/WNL.0b013e3182872e11

Sankoh, O., Sevalie, S., \& Weston, M. (2018). Mental health in Africa. The Lancet Global Health, 6(9), e954-e955. https://doi.org/10.1016/S2214-109X(18)30303-6

Savahl, S., Casas, F., \& Adams, S. (2016). Validation of the children's hope scale amongst a sample of adolescents in the Western Cape region of South Africa. Child Indicators Research, 9(3), 701-713. https://doi.org/10.1007/s12187-015-9334-2

Sharma, S., \& Singh, K. (2019). Religion and well-being: The mediating role of positive virtues. Journal of Religion and Health, 58(1), 119-131. https://doi.org/10.1007/ s10943-018-0559-5

Simoni, J.M., Frick, P.A., \& Huang, B. (2006). A longitudinal evaluation of a social support model of medication adherence among HIV-positive men and women on antiretroviral therapy. Health Psychology, 25(1), 74. https://doi.org/10.1037/0278 6133.25.1.74

Smith, G.D., \& Yang, F. (2017). Stress, resilience and psychological well-being in Chinese undergraduate nursing students. Nurse Education Today, 49, 90-95. https://doi.org/10.1016/j.nedt.2016.10.004

Stata Cooperation. (2017). Stata 15. College Station, TX: Stata Cooperation.

Statistics South Africa. (2019). Victims of crime: Governance, public safety and justice survey. Government Gazette, August. Retrieved from http://www.statssa.gov.za/ publications/P0341/P03412018.pdf

StataCorp. (2015). Stata Statistical Software: Release 14. StataCorp LP, College Station, TX: Stata Cooperation.

Steiger, J.H. (1990). Structural model evaluation and modification: An interval estimation approach. Multivariate Behavioral Research, 25(2), 173-180. https:// doi.org/10.1207/s15327906mbr2502 4

Van de Weijer, M., Baselmans, B., Van der Deijl, W., \& Bartels, M. (2018). A growing sense of well-being: A literature review on the complex framework well-being. https://doi.org/10.31234/osf.io/3rmx9

Van Zyl, Y., \& Dhurup, M. (2018). Self-efficacy and its relationship with satisfaction with life and happiness among university students. Journal of Psychology in Africa, 28(5), 389-393.

Veenhoven, R., Ehrhardt, J., Ho, M.S.D. \& De Vries, A. (1993), Happiness in nations Subjective appreciation of life in 56 nations 1946-1992, Rotterdam: Erasmus University Rotterdam.

Westen, D., \& Rosenthal, R. (2003). Quantifying construct validity: Two simple measures. Journal of Personality and Social Psychology, 84(3), 608. https://doi. org/10.1037/0022-3514.84.3.608

Wright, K.B. (2016). Communication in health-related online social support groups/ communities: A review of research on predictors of participation, applications of social support theory, and health outcomes. Review of Communication Research, 4, 65-87.

World Health Organization (WHO). (2001a). Basic documents (43rd ed.). Geneva: World Health Organization.

World Health Organization (WHO). (2001b). Strengthening mental health promotion. Geneva: World Health Organization (Fact sheet, No. 220).

World Health Organization (WHO). (2017). Depression and other common mental disorders: global health estimates (No. WHO/MSD/MER/2017.2). Geneva: World Health Organization. 